Received: 22/08/2018

\title{
Teacher Competence in Authentic and Integrative Assessment in Indonesian Language Learning
}

\section{Adnan}

Student Sebelas Maret Surakarta State University, Indonesia, adn_sbw@yahoo.com

Sarwiji Suwandi

Prof., Sebelas Maret Surakarta State University, Indonesia, sarwijiswan@yahoo.com

\section{Joko Nurkamto}

Prof., Sebelas Maret Surakarta State University, Indonesia, jokonurkamto@gmail.com

\section{Budhi Setiawan}

Dr., Sebelas Maret Surakarta State University, Indonesia, buset.74@gmail.com

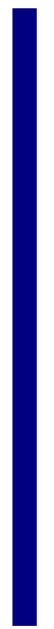

The purpose of this research is examine teacher competence in authentic and integrative assessment in Indonesian language learning. The participants of this research were 52 Indonesian language teachers at the senior high school level. Quantitative and qualitative approaches were used in this research. Data on teacher competency was used to capture authentic and integrative assessments of Indonesian language learning. The Questionnaire, interview, observation, and document analyses were used to collect the data. The data from the close-ended questionnaires, documentation, and observation were analyzed use descriptive statistic with a percentage formula. Data from open-ended questionnaires and interviews were analyzed used qualitative interactive model. The results of this research suggest that a some teachers understood definition and type an authentic and integrative assessment. Some teachers was applied authentic and integrative assessment in learning. They do not use rubrics in the assessment. Finally finding, the teacher does not have adequate competence in conducting authentic and integrative assessments. The teachers must be improved their competence to applied authentic and integrative assessment in Indonesian language learning.

Keywords: teacher competence, authentic assessment, integrative assessment, language skills, language learning

\section{INTRODUCTION}

Assessment plays an important role in learning and is a useful way for teachers to obtain feedback on students' learning (Angelo \& Cross, 1993). The functions of assessment 
include assessing individual performance assessing the effectiveness of the learning system and improving learning (Berry, 2008). The purposes of assessments are (1) diagnosing students' learning difficulties, (2) measuring learning improvements, (3) motivating student learning, (4) assessing students' mastery of knowledge and skills, (5) appraising students' ability in the classroom, (6) evaluating the method of learning, (7) evaluating the effectiveness of learning, and (8) cultivating discipline in learning and obeying rules (Dunn, 2004). Teachers should be able to provide fair assessment and encourage students to succeed in learning (Ismail, Don, Husin \& Khalid, 2018).

However, even if teachers possess general knowledge and understanding of assessment, they cannot perform language assessment well if they do not also possess a specific understanding of language learning assessment. The characteristics of language learning assessment differ from assessment in other of types learning. According to Bachman \& Palmer (1996), the assessment of language proficiency includes four skills (listening, speaking, reading, and writing) and components (grammatical, vocabulary, and pronunciation). According to Fulcher \& Davison (2012), assessments in language learning must be reflected real-world. It can be performed discretely, integratively, pragmatically, and communicatively.

Teachers can assess language learning by choosing an approach and a test type that is appropriate for the learning goals at hand. Language learning means learning how to use the language for communication in daily life. Using language for communication involves more than one's language skills. Thus, the assessment of language learning should be performed in authentic and integrative ways. Authentic assessment is directly related to practice (Burton, 2011). Integrative assessment is used to measure the more than one language skill of learners as they learn (Hughes, 2003).

Teachers should be able to effectively apply authentic assessment because authentic assessment can improve the quality of learning. According to the literature (Mintah, 2009; Finch, 2002), authentic assessment contributes to the development of self-concept and achievement motivation as well as students' attitudes, beliefs, and confidence. The integrative assessment also contributes to the development of students' language proficiency (Weigle, 2004; Plakans, 2008; Frost, Elder, \& Wiggleswon, 2011). Many studies have focused on integrative assessment (Wolfersberger, 2013; Gebril, 2010; Gebril \& Flakans, 2013), writing and reading (Sawaki, Quinlan \& Lee, 2013) or writing, reading, and listening. Authentic and integrative assessment contributes to the development of students' language proficiency. This study was conducted to determine the competence of teachers in applying authentic integrative assessment for Indonesian language skills in senior high school. The results of this study become a reference for teachers' self-reflection to improve their competence in applying authentic and integrative research. Education stakeholders can use the findings of this study to formulate a policy of developing teacher competencies in the assessment of language learning. Therefore, this research question is as follows:

1. How do teacher competencies to apply the authentic assessment in language learning?

2. How do teacher competencies to apply integrative assessment in language learning? 


\section{REVIEW OF THE LITERATURE}

\section{Teacher Competence in Assessment}

Competence involves professional skills, mindset, and behavior (Blaškováa, Blaško \& Kucharpíkováa, 2014). Competence is the ability to perform tasks based on skills, knowledge and attitudes (Hakim, 2015. Teachers can be said to have good competence in the assessment can conduct an assessment well. Teacher competency standards in conducting assessments include (1) skillfully selecting assessment methods appropriate to learning objectives, (2) skillfully developing assessment methods appropriate to the purpose of assessment, (3) skillfully processing and interpreting assessment results, (4) skillfully utilizing assessment results in making decisions about individual students, planning lessons, designing curricula, and improving schools, (5) skillfully developing valid assessment procedures, (6) skillfully communicating assessment results to students, parents, other educators, etc., and (7) skillfully recognizing assessment methods and determining their appropriateness to provide valuable information (Buros, 1990). Teachers should be able to conduct the assessment process and evaluate and process learning outcomes. Teachers utilize assessment results to determine the development of learning and the difficulties students experience in learning. Teachers can also use assessment to motivate students to learn (Fulcher, 2010).

The implementation of assessment activities is conducted in several phases, Banta \& Palomba (2015) state that the implementation phase of the assessment includes planning, implementation, and outcome (identifying and improving). Teachers should understand the eleven principles to conduct a good assessment: (1) assessment involves professional judgment, (2) assessment is based on separate principles but related to evidence on measurement and evaluation, (3) assessment decisions are influenced by a series of tensions, (4) assessment affects students' motivation and learning, (5) assessments have mistakes, (6) good assessments can improve learning, (7) good assessment requires validity, (8) assessments must be fair and ethical, (9) good assessment employs many methods, (10) good and efficient assessments should be worthy of use, and (11) good assessment employs appropriate technology (Rudner and Schafer, 2002; Brookhart, 2011).

\section{Authentic and Integrative Assessment}

According to Gulikers, Bastiaens \& Kirscner (2007), authentic assessment requires students to use and demonstrate competence, or a combination of knowledge, skills and attitudes that can be applied in real life. According to Mueller (2005), in an authentic assessment, students are asked to perform the task in question a real-world setting as an application of the knowledge and skills acquired. The authentic assessment applies problem-based learning by asking meaningful questions with real world value and stimulating students to apply their knowledge and skills (Wiggins, 1990). Blum \& Judith (1996) argue that authentic assessment should occur continuously in the context of meaningful learning environments and should reflect real-life experiences that can be documented through observation, anecdotal notes, journals, diaries, work samples, 
conversations, portfolios, writing, discussions, experiments, presentations, exhibitions, projects, and other methods.

Furthermore, Bagnato (2007) states that authentic assessment entails careful planning to investigate children's behavior in a natural way. Information is obtained through direct observation and recording, interviews, rating scales and naturalistic observational samples or by facilitating play and activity in children's everyday life. Authentic assessment is a procedure for evaluating student achievement or by using performance activities and tasks that represent class goals, curricula, and real-world situations (Atac, 2012).

Authentic assessment is focused on giving tasks to students as an actualization of their knowledge and skills as they will be applied in the real world. Authentic assessment is a form of evaluation to describe the real knowledge and skills students obtain as a result of learning activities. Authentic assessments can be performed using several techniques, such as product assessment, project assessment, portfolio assessment, self-assessment, peer assessment, written exams, journals, and observation (Olfos \& Zulantay, 2007).

Integrative assessment should be performed by combining various aspects of assessment within a certain period. According to Gabril (2018), integrative assessment is a popular assessment technique used to measure student abilities, such as writing to speak and others. Integrative assessment is performed by combining ability assessment and reflective skills in practical tasks. Hughes (2003) notes that integrative assessment requires a comparative skill evaluation for a student in completing a task. This means that assessing one aspect of language can also involve other aspects or that the assessment of skills using language can involve other language skills, both receptive and productive.

\section{METHOD}

\section{Design}

This research is a mixed method research, which combined qualitative and quantitative methods. This study used explanatory-sequential design that begins with the collection of quantitative data and analysis quantitative data then qualitative data collection is carried out. The mixed method design is used to obtain comprehensive information about language teacher competencies on authentic and integrative assessment.

\section{Participants}

The Participants in this research were 52 (18 male and 34 female) of Indonesian language teachers in 17 or all high schools in Sumbawa regency of West Nusa Tenggara Province, Indonesia. They consisted of senior and junior teachers in every school. Senior teachers are those who have taught for more than 10 years and have obtained a professional educator certificate from the government. Junior teachers are those who have taught for less than five years. They have no educator certificate from the government. This research is a population research because the sample is all of Indonesian language teachers high school teachers in public schools in Sumbawa district of West Nusa Tenggara Province, Indonesia. 


\section{Data Collection Techniques}

The data for this research was qualitative and quantitative. The data described the teachers' skills in applying authentic and integrative assessment in Indonesian language learning. Quantitative data were collected using a questionnaire technique. Qualitative data were collected through interviews, observation and document analysis. The purpose of the interviews was to collect information on teachers' understanding and skills in applying authentic and integrative assessment. The observation technique was used to gather information about teachers' authentic and integrative assessment. The aim of the documentation techniques was to collect documentation on the authentic and integrative assessments implemented by Indonesian language teachers.

\section{Data Collection Procedures}

The data collection techniques involved several phases. Data collection began by asking the participants to complete the questionnaire. The data reflected the participants' assessment practice. The teachers had conducted assessments for many years prior to this research. The researchers checked the information obtained from the questionnaires through teacher interviews. After conducting the interviews, the next step was to gather the teachers' documents. These papers served as supporting evidence that the teachers had applied authentic and integrative assessment in learning. Then, the researchers observed assessment activities in the classroom to ensure the validity of the information gathered previously through the questionnaires, interviews, and document analysis. After the data collection was completed, the last step was to interpret the research results.

\section{Instruments}

The instruments of this research were questionnaires, interviews guide, observations guide, and documentation guide. There were 21 items on the questionnaire, including 16 closed-ended questions and five open-ended questions. The sample of items questions: "Are you applied authentic assessment in listening?" choice items yes or no (closedended questions). "Write the type of authentic assessment were you used in listening on the blank colom", (open-ended questions. There were 12 items questions interviews, 12 items observation checklist, and 12 items observation checklist. One sample of interviews, "can you explain, how you doing authentic assessment in listening?" The purpose the teacher interviews were to obtain information about the authentic and integrative assessments that they had applied in learning. The observation was performed to obtain a direct understanding of the application of authentic and integrative assessment activities in the learning process. "There is an attitude assessment rubric document" choice items there are or no (ex item document checklist). Documentation on the assessments that teachers had administered was gathered as a reference. One sample of checklist items of observation, "Teacher used attitude assessment rubric on reading assessment in classroom" choice items are yes or no.

\section{Validity and Reliability of Instrument}

The testing validity of open-ended questionnaire items used the production moment formula. The test results show that 16 of the questionnaire items are valid. Reliability 
test of open questionnaire used alpha formula with the results of 0.79 . The testing validity open-ended questionnaire items, interview questions, observation guide statements, and documentation checklist sheets using the content validity test by asking for consideration of tow experts. Open-ended questionnaire reliability test, interview, observation and document analysis guide using Kappa formula with sig 0.73, 0.65, and 0.84 .

\section{Data Analysis Techniques}

The data were analyzed using quantitative and qualitative descriptive analysis. The close-ended questionnaires, documents, and observations were analyzed through quantitative descriptive analysis specifically by calculating a percentage. The data from open-ended questionnaires and interviews were analyzed through qualitative descriptive analysis and used the Miles, Huberman \& Saldana (2014) model, which involved the following steps: collecting the data, reducing the data, presenting the data, and forming a conclusion.

\section{FINDINGS}

\section{Teacher Competence in Applying Authentic Assessment}

Authentic assessment is a type of assessment that can be used in language learning. The results of authentic assessment reflect students' ability and skills to use language in real world situations for communication. The results of this research show that some teachers understood authentic assessment and applied it in Indonesian language learning. The questionnaire data indicate that 15 teachers (29\%) understood authentic assessment, whereas 37 teachers $(71 \%)$ did not understand authentic assessment. When they were asked to define authentic assessment, not all teachers could explain it. Most teachers were unfamiliar with the type and form of authentic assessment in language learning, but they had applied authentic assessment to learning with regard to listening, speaking, reading and writing. Of the teachers, $21(40 \%)$ claimed that they had applied authentic assessment to listening skills, while 20 teachers (38\%) had applied authentic assessment to speaking skills. Twenty-two teachers had implemented an authentic assessment for reading skills (42\%). Twenty-four teachers (46\%) had used an authentic assessment for writing skills. These results are presented in Table 1 below.

Table 1

Number of Teachers' who Understood and had Applied Authentic Assessment in Indonesian Language Skills

\begin{tabular}{clll}
\hline No & \multicolumn{1}{c}{ States } & NGAA & Percentage \\
\hline 1. & Understood authentic assessment & 15 & $29 \%$ \\
\hline 2. & Understood the types of authentic assessment & 9 & $17 \%$ \\
\hline & Applied authentic assessments in & & \\
3. & Listening & 21 & $40 \%$ \\
\hline 4. & Speaking & 20 & $38 \%$ \\
\hline 5. & Reading & 22 & $42 \%$ \\
\hline 6. & Writing & 24 & $46 \%$ \\
\hline
\end{tabular}


The number of participants was 52 teachers; NGAA = number of teachers understanding and applying the assessment.

The table shows that some Indonesian language teachers have applied authentic assessment for listening, speaking, reading and writing skills. Teachers applied authentic assessment in language learning, namely, performance and production assessment. The authentic assessments used for listening skills were writing and retelling what students had heard. Authentic assessments applied to speak skills included interviews, discussion, and storytelling. Teachers had applied authentic assessment of reading skills in the form of demonstration and storytelling. Authentic assessment of writing skills included portfolio assessments, writing narrative texts or persuasion texts, making proposals, journaling and reporting observations. These results are presented in the Table 2 below.

Table 2

Form of Authentic Assessment Applied to Indonesian Language Skills

\begin{tabular}{|c|c|c|c|c|}
\hline $\mathrm{F}_{\text {Form of Task }}^{\text {Skill }}$ & Listening & Speaking & Reading & Writing \\
\hline Performance & $7(13 \%)$ & $15(29 \%)$ & $24(46 \%)$ & $9(17 \%)$ \\
\hline Product & $5(10 \%)$ & $3(6 \%)$ & $9(17 \%)$ & $19(37 \%)$ \\
\hline Portfolio & & & & $6(12 \%)$ \\
\hline Writing result of listening & $20(38 \%)$ & & & \\
\hline Telling result of listening & $25(48 \%)$ & & & \\
\hline Interview & & $8(15 \%)$ & & \\
\hline Discussion & & $17(33 \%)$ & & \\
\hline Speech & & $14(27 \%)$ & & \\
\hline Demonstration & & $14(27 \%)$ & $11(21 \%)$ & \\
\hline Storytelling & & & $6(30 \%)$ & \\
\hline Writing narration and persuasion text & & & & $15(29 \%)$ \\
\hline Making proposals & & & & $9(17 \%)$ \\
\hline Journaling & & & & $1(2 \%)$ \\
\hline Reporting observations & & & & $13(25 \%)$ \\
\hline Other & & $1(2 \%)$ & & \\
\hline
\end{tabular}

The number of participants were 52 teachers.

The table shows that some teachers had applied an authentic assessment to Indonesian language skills. The types of authentic assessments applied were, performance assessment, product assessment, portfolio assessment, telling the results of listening, interviews, discussions, speech, demonstrations and storytelling. These were administered as part of the student performance assessment. Therefore, writing reports on listening, writing narrative and persuasive text, making proposals, journaling, and writing reports on observations were conducted as part of the product assessment.

The results of the document analysis indicate that almost all teachers used performance assessment, production assessment, portfolios, project assessment, and self-assessment in their lesson plans. The teachers do not have task instruction documents, and student task documents. The results of the interviews indicated that some teachers had applied 
authentic assessment in learning. Forms of authentic assessment used by some teachers in learning were performance assessment and product assessment. Attitude assessment is an aspect of authentic assessment and was used by some teachers in learning. Teachers performed attitude assessment in learning for four skills: listening, speaking, reading, and writing. Fifteen teachers (29\%) claimed that they had applied attitude assessment for listening skills, 21 teachers (40\%) had applied attitude assessment for speaking skills, and 15 teachers $(29 \%)$ had applied attitude assessment for reading skills. Seventeen teachers $(33 \%)$ had applied attitude assessment for writing skills. Further details on these results are presented in Table 3 below.

Table 3

Number of Teachers who Applied Attitude Assessment in Language Skills

\begin{tabular}{clll}
\hline No & \multicolumn{1}{c}{ Statements } & NGAAA & Percentage \\
\hline 1. & Conducted attitude assessment on: Listening & 15 & $29 \%$ \\
\hline 2. & Speaking & 21 & $40 \%$ \\
\hline 3. & Reading & 15 & $29 \%$ \\
\hline 4. & Writing & 17 & $33 \%$ \\
\hline
\end{tabular}

The number of participants was 52 teachers; NTAA = number of teachers who had applied attitude assessment.

The results of the interviews and observations indicated that teachers used attitude assessments by observing students' attitudes and behaviors during classroom learning activities. Teachers only recorded the student's name and marked those who had a negative attitude in the classroom. Teachers assessed students' attitudes in learning without using a rubric for attitude assessment. Some teachers used the rubric of authentic assessment for four skills: listening, speaking, reading and writing. The data from the questionnaire show that 11 teachers (21\%) used the rubric assessment for listening; nine teachers (17\%) used the rubric assessment for speaking; 15 teachers (29\%) used the reading comprehension rubric; and 12 teachers $(23 \%)$ used the rubric assessment for writing skills. These results are presented in Table 4 below.

Table 4

Number of Teachers who Used Rubric Assessment

\begin{tabular}{clll}
\hline No & \multicolumn{1}{c}{ Assessment Aspect } & NUTR & Percentage \\
\hline & Make and use assessment rubric & & \\
\hline 1. & Listening & 11 & $21 \%$ \\
\hline 2. & Speaking & 9 & $17 \%$ \\
\hline 3. & Reading & 15 & $29 \%$ \\
\hline 4. & Writing & 12 & $23 \%$ \\
\hline
\end{tabular}

The number of participants was 52 teachers; NTUR = number of teachers used rubric

The table above shows that few teachers compiled and used assessment rubrics for listening and writing skills. However, few teachers made and used assessment rubrics for speaking and reading skills. The results of the interviews indicated that some teachers had compiled and used an assessment rubric. Data from the observations indicated that the all teachers did not use an assessment rubric. All teachers did not have 
assessment documents, such as task instructions and assessment rubrics. Only a few teachers included an assessment rubric in their lesson plan document, but the assessment rubric was not used when conducting the assessments, which is necessary for teachers apply authentic assessment in learning. Thus, it can be concluded that teachers did not have adequate competence in applying authentic assessment.

\section{Teacher Competence in Applying Integrative Assessment}

Integrative assessment is one type of assessment used in language learning, but it was not well understood by the teachers. The Indonesian teachers did not understand the definition of integrative assessment. The data from the questionnaires completed by 52 teachers revealed that 16 teachers $(31 \%)$ understood the definition of an integrative assessment whereas 36 teachers $(69 \%)$ reported that they did not understand the definition of integrative assessment. The results of the interviews indicated that almost no Indonesian language teachers understood the definition of integrative assessment. Almost all Indonesian language teachers stated that they had applied an integrative assessment in Indonesian language learning. The questionnaire data revealed that 14 teachers $(27 \%)$ stated that they had applied integrative assessment in Indonesian language learning, and $38(73 \%)$ reported that they had not applied integrative assessment in Indonesian language learning. The teachers had applied an integrative assessment of knowledge, skills (listening, speaking, reading, and writing) and attitudes. The teachers integrated assessment into the learning process. Further details on these results can be seen in Table 5 below.

Table 5

Number of Teachers Applying Integrative Assessment

\begin{tabular}{|c|c|c|c|}
\hline No & Form of Integrative Assessment & NTA & Percentage \\
\hline 1. & Knowledge and skill & 17 & $33 \%$ \\
\hline 2. & Knowledge and attitude & 11 & $21 \%$ \\
\hline 3. & Skill and attitude & 21 & $40 \%$ \\
\hline 4. & Listening and attitude & 5 & $10 \%$ \\
\hline 5. & Speaking and attitude & 12 & $23 \%$ \\
\hline 6. & Reading and attitude & 9 & $17 \%$ \\
\hline 7. & Writing and attitude & 15 & $29 \%$ \\
\hline 8. & Knowledge, skill and attitude & 13 & $25 \%$ \\
\hline 9. & Assessment and learning & 23 & $44 \%$ \\
\hline 10. & Language learning materials with other learning materials & 0 & $0 \%$ \\
\hline 11. & Listening and writing & 11 & $21 \%$ \\
\hline 12. & Listening and speaking & 25 & $48 \%$ \\
\hline 13. & Listening and reading & 0 & $0 \%$ \\
\hline 14. & Reading and writing & 15 & $29 \%$ \\
\hline 15. & Reading and speaking & 8 & $15 \%$ \\
\hline 16. & Reading, listening and speaking & 0 & $0 \%$ \\
\hline 17. & Reading, listening, and speaking & 0 & $0 \%$ \\
\hline 18. & Reading, writing, speaking and listening & 3 & $6 \%$ \\
\hline 19. & Others & 0 & $0 \%$ \\
\hline
\end{tabular}


The number of participants were 52 teachers; NTA = number of teachers that applied the assessment in question.

The table reveals that some teachers applied integrative assessment in knowledge, skills, and attitudes, and some teachers have applied an integrative assessment of skills and attitudes. Some teachers applied an integrative assessment of skills. Some teachers combined assessment and learning. No teacher applied an integrative assessment of every lesson or subject. It is means that most teachers do not applied an integrative assessment in Indonesian language learning.

The data showed that the teachers did not use assessment rubrics to conduct integrative assessments. The questionnaire data revealed that five teachers (10\%) used integrative rubric scoring; 42 teachers $(90 \%)$ did not use an assessment rubric. It is means that most teachers do not used an integrative assessment rubric in Indonesian language learning. The results of the document analysis indicated that no teachers had an integrative assessment rubric and instruction task. The results of the observations indicated that all teachers did not used rubrics to perform integrative assessments. It is means that the teachers did not apply integrative assessment well in learning.

\section{DISCUSSION}

Language learning refers to learning how to use language for communication in daily life. Therefore, language learning materials must authentically reflect real life. The assessment of language learning is performed in an integrative way. According to Atac (2012), there are several reasons for using authentic assessment in learning: (1) it can yield direct measurements, (2) it can capture the real meaning of learning, (3) it can integrate assessment and teaching, and (4) it can be demonstrated empirically. Authentic assessment is able to develop students' motivation and achievement in learning (Fook \& Sidhu, 2010; Whitelock, 2012). Furthenmore, authentic assessment integrates continuing learning activities, and can improve ability and critical and creative thinking (Pantiwati, 2013).

Many types of authentic assessments can be used by teachers in language learning. According to O'Malley \& Pierce (1996), authentic assessments in language learning can be classified into several types: (1) oral interviews, (2) telling stories or summarizing a text, (3) writing examples of narrative or persuasive writing, (4) preparing proposals, (5) demonstrating experiments, (6) composing questions, (7) teacher observation, and (8) portfolios. Various types of authentic assessment can be used by teachers in language learning in accordance with the material and learning objectives.

The results of this research show that teachers applied performance assessments, and product assessments of Indonesian language skills. However, these assessments were not implemented well because they were not supported by adequate assessment tools, such as scoring guidelines and assessment rubrics. The other types of authentic assessment were not applied by teachers.

This study shows that teachers do not yet possess sufficient competence to apply authentic assessment in learning because their understanding of this assessment were is 
insufficient. Authentic assessment can improve student achievement. According to Romovaa \& Andrew (2011), portfolio assessment can increase student comprehension in writing. According to Baniabdelrahman (2010), self-assessment studies have a positive effect on reading comprehension performance. Self-assessment affects student independence and writing competence (Ratminingsih, Marhaeni \& Vigayanti, 2018). Integrative assessment of reading and listening (Gobel, 2011; Gobel \& Kano, 2014) and integrative assessment of speaking (Lee, 2006; Barkaoui, Brooks, Swain \& Lapkin, 2013) can improve students' learning motivation. Huang \& Hung (2010) found that students preferred reading to speaking assignments. Student attitudes toward independent and integrated assessments of speaking performance were relatively similar (Huang \& Hung, 2013). Thus, it is preferable to assess speaking integratively with reading to independently assess speaking.

There are advantages to using integrative assessment in learning: (1) simultaneously measuring a number of outcomes, (2) applying unified assessment criteria with the same assessment components, (3) using the same number of standard inter-component units, (4) the incorporation of varied methods and assessment instruments, 5) a basis in facts occurring in class, and (6) assessment results can be obtained and integrated from various sources (SAQA, 2001: 55). However, the results of this research show that teachers do not yet possess an adequate understanding of integrative assessment. Most teachers stated that they did not apply integrative assessment in learning, despite having actually applied it. Some reported that they claimed that they had not applied it because they did not realize that they had. The forms of integrative assessments applied by teachers in language learning were the integrative assessment of listening and speaking skills, listening and writing, and reading and writing.

Teachers have not effectively implemented integrative assessment because there has not been proper planning and implementation. Teachers did not engage in planning before conducting assessments, such as preparing task instructions, scoring guides and assessment rubrics. Conceptually, task instructions and assessment rubrics should be prepared before an assessment. According to Sundeen (2014), generally, the use of rubrics can facilitate teachers' scoring process and improve the quality of students' writing in the assessment of writing skills.

Teachers were unable to effectively apply an integrative assessment of knowledge, skills, and attitudes and to effectively perform integrative assessment across skills. None of the teachers had performed an integrative assessment between one language lesson and the next. According to Gaskins, Guthrie, Satlow, Ostertag, Six, Byrne, \& Connor (1994), integrating science, reading and writing could greatly enhance students' understanding of concepts and applications. According to Short (1993), the language assessment could be integrated with teaching materials. Most teachers in this study integrated language assessments with teaching materials.

The teachers in this study applied integrative authentic assessment through the integration of knowledge and skills, knowledge assessment and attitudes, and the assessment of a given type of language skills and other Indonesian language skills. Teachers conducted out integrative assessments in learning Indonesian by assigning 
performance tasks and production tasks. However, the teachers were unable to properly perform the authentic assessment and integrative assessment because they were not supported by adequate assessment tools. This means that the teachers were unable to properly apply the authentic and integrative assessments of Indonesian language skills. The teachers lacked adequate competence in performing an authentic integrative assessment of Indonesian skills. PISA (2015) found that the average reading ability score of Indonesian students was 397 indicating that the country ranked 61 out of 72 countries surveyed. These data showed that students' reading ability was very low. These problems need to be studied scientifically to determine whether the low reading ability of students is the result of learning and the assessment of language learning. This assessment has yet to be condected in an authentic and integrative way. According to ElCoumy (2009), performance assessment effectively developed reading skills of students.

\section{CONCLUSION}

Authentic and integrative assessment is an appropriate assessment model for Indonesian language learning because it provides a positive contribution to the development of students' language skills. Fifteen teachers (29\%) have understood, nine teacher (17\%) know type of authentic assessment. Some teachers have applied authentic assessment in Indonesian language learning. The authentic assessment has been used by some teachers, specifically in the form of performance assessment and product assessment. Authentic assessment has not been applied well because teachers do not use assessment rubrics and/or receive proper guidance.

Sixteen teachers $(31 \%)$ understood the definition of an integrative assessment and 14 teachers $(27 \%)$ used integrative assessment in learning, specifically in the integrative assessment of language skills (writing-speaking, reading to writing, reading to writinglistening-speaking). Some teachers also applied integrative assessments of knowledge, skills, and attitudes. The teachers were unable to properly apply integrative assessments because they did not use assessment rubrics or scoring instructions. It can be concluded that teachers have not properly applied authentic or integrative assessments because their understanding is not yet sufficient.

\section{IMPLICATIONS}

Assessment in language learning must be done in an authentic and integrative way. Learning languages is learning to use language for various communication purposes. Language is used integratively in communication. Therefore, language teachers are advised to carry out authentic and integrative language learning and assessment. Teachers need to improve their competence about authentic and integrative assessments. Education stakeholders need to consider the results of this study to make policies for improving teacher competency in assessment.

\section{REFERENCES}

Angelo, T.A. \& Cross, K.P. (1993). Classroom assessment techniques: A handbook for college teachers. Sanprasico: Josszy-Bass Inc. 
Ataç, B. A. (2012). Foreign language teachers' attitude toward authentic assessment in language teaching. The Journal of Language and Linguistic Studies, 8 (2), 7-19.

Bachman, L. F. \& Palmer, A.S. (1996). Language testing in practice: Designing and developing useful language tests. New York: Oxford University Press.

Bagnato, S.J. (2007). Authentic assessment for early childhood intervention. New York: The Guilford Press.

Banta, T. W. \& Palomba, C.A. (2008). Assessment essentials: Planning, implementing, and improving assessment in higher education. San Francisco: John Wiley \& Sons, Inc.

Barkaoui, K., Brooks, L., Swain, M., \& Lapkin, S. (2013). Test-takers' strategic behaviors in independent and integrated speaking tasks. Applied Linguistics, 34, 304324.

Baniabdelrahman, A. A. (2010). The effect of the use of self-assessment on EFL students' performance in reading comprehension in english. The Electronic Journal for English as a Second Language, 14 (2), 1-22. Retrieved June 17th, 2016 from http://www.tesl-ej.org/wordpress/issues/volume14 /ej54/ej54a2/

Berry, R. (2008). Assessment for learning. Hong Kong: Hong Kong University Press.

Blaškováa, M., Blaškoa, R., \& Kucharpíkováa, A. (2014). Competences and competence model of university teachers. Procedia - Social and Behavioral Sciences, $159,457-46$.

Blum, R.E. \& Judith, A. A. (1996). A Handbook for student performance assessment in an era of restructuring. Alexandria, Va: Association for Supervision and Curriculum Development.

Brookhart, S. M. (2011). Educational assessment knowledge and skills for teachers. Educational Measurement: Issues and Practice, 30 (1), 3-12.

Buros (1990). Standards for teacher competence in educational assessment of student. Retrieved from http://buros.org/standards-teacher-competence-educational-assessmentstudent

Burton, K. (2011). A framework for determining the authenticity of assessment tasks: Applied to an example in law. Journal of Learning Design, 4 (2), 20-28.

Dunn, L., Morgan, C., O’Reilly, M., \& Parry, S. (2004). The student assessment handbook. New York: Taylor \& Francis Group.

El-Koumy, A.S.A.K. (2009). The effect of classroom performance assessment on EFL students' basic and inferential reading skills. Reitrived from https://files.eric.ed.gov/fulltext/ED514530.pdf

Finch, A.E. (2002). Authentic assessment: Implications for EFL performance testing in Korea. Journal Secondary Education Research, 49 (0), 89-122. 
Fook, C.S. \& Sidhu, .G.K. (2010). Authentic assessment and pedagogical strategies in higher education. Journal of Social Sciences, 6 (2), 153-161.

Frost, K., Elder, C. \& Wiggleswon, G. (2011). Investigating the validity of an integrated listening-speaking task: A discourse-based analysis of test takers' oral performances. Language Testing, 29 (3), 345-369.

Fulcher, G. (2010). Practical language testing. London: Hodder Education, An Hachette UK Company.

Fulcher, G. \& Davidson, F. (2012). The routledge handbook of language testing. London: Routledge.

Gaskins, I.W., Guthrie, J.T., Satlow, P.E., Ostertag, J., Six, L., Byrne, J., \& Connor, B. (1994). Integrating instruction of science, reading, and writing: Goals, teacher development, and assessment. Journal of Research in Science Teaching, 31 (9), 10391056.

Gebril, A. (2010). Bringing reading-to-write and writing-only assessment tasks together: A generalize ability analysis. Assessing Writing, 15 (2), 100-117.

Gebril, A. \& Flakans, L. (2013). Toward a transparent construct of reading-to-write tasks: The interface between discourse features and proficiency. Language Assessment Quarterly, 10 (1), 9-27.

Gebril, A. (2018). Integrated-skills assessment. The TESOL Encyclopedia of English Language Teaching, 1-7.

Gobel, P. (2011). The effect of reading while listening on TOEFL gains. Forum of Higher Education Research, 1 (0), 45-51.

Gobel, P. \& Kano, M. (2014). Implementing a year-long reading while listening program for Japanese University EFL students. Computer Assisted Language Learning, 27 (4), 279-293.

Gulikers, J.T.M., Bastiaens, T.J. \& Kirschner, P.A. (2007). Authentic assessment, student and teacher perceptions: The practical value of the five dimensional-framework. Journal of Vocational Education and Training, 58 (3), 337-357.

Hakim, A. (2015). Contribution of competence teacher (pedagogical, personality, professional competence and social) on the performance of learning. The International Journal Of Engineering And Science (IJES), 4 (2), 01-12.

Huang, H.T., \& Hung, S.T. (2010). Examining the practice of a reading-to-speak test task: Anxiety and experience of EFL students. Asia Pacific Education Review, 11, 235242.

Huang, H.T., \& Hung, S.T. (2013). Comparing the effects of test anxiety on independent and integrated speaking test performance. Tesol Quarterly, 47 (2), 224-269. 
Hughes, A. (2003). Testing for Language Teachers. Cambridge: Cambridge University Press.

Ismail, S. N., Don, Y., Husin, F., \& Khalid, R. (2018). Instructional leadership and teachers' functional competency across the 21 st century learning. International Journal of Instruction, 11 (3), 135-152.

Lee, Y.W. (2006). Dependability of scores for a new ESL speaking assessment consisting of integrated and independent task. Language Testing, 23 (2), 131-166.

Mintah, J.K. (2009). Authentic assessment in physical education: Prevalence of use and perceived impact on students' self-concept, motivation, and skill achievement. Journal of Measurement in Physical Education and Exercise Science, 7 (3), 161-174.

Miles, M.B., Huberman, A.M., \& Saldana, J. (2014). Qualitative data analysis. Washington: Sage Publication, Icn.

Mueller, J. (2005). The authentic assessment toolbox: Enhancing student learning trough on line faculty development. Journal online learning and teaching, 1 (1), 13-35.

O'Malley, M. \& Pierce, L.V. (1996). Authentic assessment for English language learners. New York: Addison Wesley.

OECD. (2016). PISA 2015 in focus. Retrieved April 11th, 2018 from https://www.oecd.org/pisa/pisa-2015-results-in-focus.pdf

Olfos, R. \& Zulantay, H. (2007). Reliability and validity of authentic assessment in a web based course. Journal of Educational Technology \& Society, 10 (4), 156-173.

Pantiwati, Y. (2013). Authentic assessment for improving cognitive skill, critical creative thinking and meta-cognitive awareness. Journal of Education and Practice, 4 (14), 1-9.

Plakans, L. (2008). Comparing composing processes in writing only and reading-towrite test tasks. Assessing Writing, 3 (2), 111-129.

Ratminingsih, N. M., Marhaeni, A.A.I.N., \& Vigayanti, L.P.D. (2018). Self-assessment: The effect on students' independence and writing competence. International Journal of Instruction, 11 (3), 277-290.

Romovaa, Z. \& Andrewb, M. (2011). Teaching and assessing academic writing via the portfolio: Benefits for learners of English as an additional language. Assessing Writing, $16(2), 111-122$.

Rudner, Lawrence M. \& Schafer, Willian D. (2002) What teachers need to know about assessment. Washington DC: National Education Association.

SAQA. (2001). Criteria and guidelines for the assessment of NQF registered unit standards and qualifications. Pretoria: SAQA. 
Sawaki, Y., Quinlan, T., \& Lee, Y.W. (2013). Understanding learner strengths and weaknesses: Assessing performance on an integrated writing task. Language Assessment Quarterly, 10 (1), 73-95.

Short, D.J. (1993). Assessing integrated language and content instruction. Tesol Quarterly, 27 (4), 627-654.

Sundeen, T.H. (2014). Instructional rubrics: Effects of presentation options on writing quality. Assessing Writing, 21 (0), 74-88.

Weigle, S. C. (2004). Integrating reading and writing in a competency test for nonnative speaker of English. Journal of Assessing Writing, 9 (0), 27-55.

Whitelock, D. \& Cross, S. (2012). Authentic assessment: What does it mean and how is it instantiated by a group of distance learning academics? International Journal of $e$ Assessment, 2 (1), 1-10.

Wiggins, G. (1990). The case of authentic assessment: Practical assessment, research, and evaluation, 2(2), 1-8. Retrieved Augusts 15th, 2017 from http://pareonline.net/getvn.asp? $\mathrm{v}=2 \& \mathrm{n}=2$

Wolfersberger, M. (2013). Refining the construct of classroom based writing-Fromreadings assessment: The role of task representation. Language Assessment Quarterly, 10 (1), 47-72. 